\section{Reversible S-S Bond Breaking and Bond Formation in Disulfide-Containing Dinuclear Complexes of $\mathrm{Mn}^{\mathrm{I} * *}$}

Javier Ruiz,* Mario Ceroni, Oscar V. Quinzani, Víctor Riera, and Oscar E. Piro

Disulfide-containing compounds are of considerable biological ${ }^{[1]}$ and technological relevance, ${ }^{[2]}$ and the mechanisms by which the sulfur-sulfur bond in these compounds can be reversibly broken and formed has attracted a great deal of interest. ${ }^{[3]}$ We have recently reported that nucleophilic degradation of cyclooctasulfur by the diphosphanylmethanide complex of manganese(I) $\left[\mathrm{Mn}(\mathrm{CO})_{4}\left\{\left(\mathrm{PPh}_{2}\right)_{2} \mathrm{CH}\right\}\right]$ allows the formation of the hexasulfur-bridged bis(diphosphanylmethanide ) dimetallic derivative $\left[(\mathrm{CO})_{4} \mathrm{Mn}\left\{\left(\mathrm{PPh}_{2}\right)_{2} \mathrm{C}-\mathrm{S}_{6}-\mathrm{C}\left(\mathrm{PPh}_{2}\right)_{2}\right\}\right.$ $\left.\mathrm{Mn}(\mathrm{CO})_{4}\right]^{\left[{ }^{[4]}\right.}$ In this complex the polysulfur chain can be progressively shortened by treatment with $\mathrm{PPh}_{3}$ leading finally to the disulfide compound $\mathbf{1}$, which does not undergo further sulfur extrusion processes. ${ }^{[5]}$ We have now explored the chemistry of this disulfide derivative with regard to the controlled scission and formation of the sulfur-sulfur bond, promoted either by redox processes or by combined redox and acid-base treatments. This has led to a number of scarce functionalities such as diphosphanylthioketone, sulfenyl iodide, and thioxophosphorane ylide, as parts of the corresponding carbonyl complex of manganese(I).

$\left[(\mathrm{CO})_{4} \mathrm{Mn}\left\{\left(\mathrm{PPh}_{2}\right)_{2} \mathrm{C}-\mathrm{S}-\mathrm{S}-\mathrm{C}\left(\mathrm{PPh}_{2}\right)_{2}\right\} \mathrm{Mn}(\mathrm{CO})_{4}\right] \quad \mathbf{1}$

The treatment of $\mathbf{1}$ with one equivalent of $\mathrm{I}_{2}$ in dichloromethane led instantaneously to the formation of 2 (Scheme 1), which was isolated as a red solid. The spectroscopic and analytical data for $\mathbf{2}$ (see Experimental Section), as well as further reactivity studies (see below), strongly support the proposed formulation for this complex as the sulfenyl iodide derivative $\left[\mathrm{Mn}(\mathrm{CO})_{4}\left\{\left(\mathrm{PPh}_{2}\right)_{2} \mathrm{C}-\mathrm{S}-\mathrm{I}\right\}\right]$. The Raman spectrum of $\mathbf{2}$ is in agreement with the scission of the $\mathrm{S}-\mathrm{S}$ bond upon oxidation with iodine, since it shows the complete disappearance of the strong $\mathrm{S}-\mathrm{S}$ stretching band at $321 \mathrm{~cm}^{-1}$ which corresponds to the disulfide moiety in the starting complex 1. Reduction of 2 with $\mathrm{Na}$ in THF quantitatively

[*] Dr. J. Ruiz, M. Ceroni, Prof. Dr. V. Riera

Departamento de Química Orgánica e Inorgánica

Facultad de Química, Universidad de Oviedo

33071 Oviedo (Spain)

Fax: $(+34)$ 98-510-3446

E-mail: jruiz@sauron.quimica.uniovi.es

Dr. O. V. Quinzani

Departamento de Química e Ingeniería Química

Universidad Nacional del Sur

8000 Bahía Blanca (Argentina)

Dr. O. E. Piro

Departamento de Física

Facultad de Ciencias Exactas

Universidad Nacional de La Plata and IFLP (CONICET)

C.C. 67. 1900 La Plata (Argentina)

[**] This work was supported by the Spanish Ministerio de Educación y Ciencia (Project No. DGES-96-PB-0317). We thank the Agencia Española de Cooperación Internacional for a postgraduate studentship to M.C.

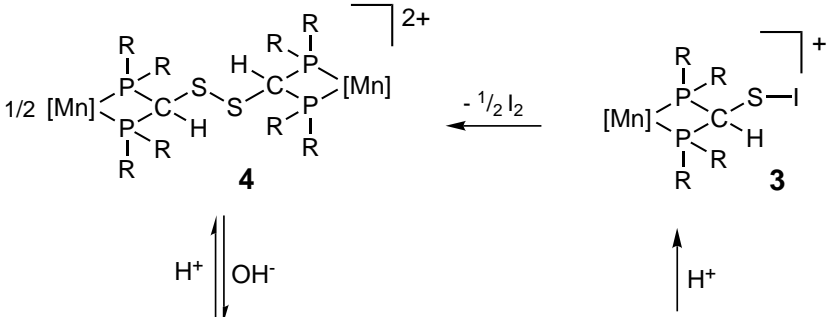

<smiles>[N+]=CC=CC=[Te]</smiles>


Scheme 1. Reversible scission and formation of the $\mathrm{S}-\mathrm{S}$ bond in $\mathbf{1}$, and synthesis of the ylide derivative 6. $[\mathrm{Mn}]=\mathrm{Mn}(\mathrm{CO})_{4}{ }^{+} \cdot \mathrm{R}=\mathrm{Ph}$.

regenerates the disulfide $\mathbf{1}$. The sulfur-sulfur bond formation to give $\mathbf{1}$ is also accomplished by passing $\mathbf{2}$ through an alumina column and, partially, by heating a solid sample of $\mathbf{2}$ under vacuum at about $200^{\circ} \mathrm{C}$. In spite of their biochemical interest (e.g., as intermediates in the iodination of tyrosine), thermally stable sulfenyl iodides are scarce owing to their very favored disproportionation [Eq. (1)]. ${ }^{[6]}$ For this reason, they had never

$2 \mathrm{RSI} \longrightarrow \mathrm{RSSR}+\mathrm{I}_{2}$

been prepared by direct reaction of a disulfide with iodine. In our case, the noteworthy stability of $\mathbf{2}$ could be due to the anionic character of the diphosphanyl methanide ligand $\left\{\left(\mathrm{PPh}_{2}\right)_{2} \mathrm{C}-\mathrm{S}-\mathrm{I}\right\}^{-}$in which the sulfenyl iodide functionality is included. In fact, when $\mathbf{2}$ was protonated at the methanide carbon atom (using $\mathrm{HBF}_{4}$ ), the opposite reaction was immediately observed (even at low temperature) yielding the dication 4 and $I_{2}$, instead of the mononuclear species 3 (Scheme 1). This means that the sulfur-sulfur bond is once again easily regenerated by treatment with acids. Naturally, the cationic derivative $\mathbf{4}$ is transformed into $\mathbf{1}$ by simple reaction with $\mathrm{KOH}$.

The sulfur-sulfur bond in $\mathbf{1}$ can also be broken by oxidation by using two equivalents of $\mathrm{AgBF}_{4}$. This led to 5, which, on reduction with $\mathrm{Na}$ in $\mathrm{THF}$, readily regenerated $\mathbf{1}$. The cationic complex $\mathbf{5}$ can also be prepared through iodide abstraction from 2, by using either TIPF 6 or an excess of $\mathrm{I}_{2}$, which abstract iodide as TII and $\mathrm{I}_{3}{ }^{-}$, respectively. To the best of our knowledge, diphosphanylthioketones are unknown, although the related carbodiphosphorane thiolate and selenolate zwitterions $\mathrm{PPh}_{3} \mathrm{C}(\mathrm{X}) \mathrm{PPh}_{3}(\mathrm{X}=\mathrm{S}, \mathrm{Se})$ have been described, ${ }^{[7]}$ as has the coupling of two selenolate functions upon oxidation to afford the cation $\left[\left(\mathrm{PPh}_{3}\right)_{2} \mathrm{C}-\mathrm{Se}-\mathrm{Se}-\mathrm{C}\left(\mathrm{PPh}_{3}\right)_{2}\right]^{2+} \cdot{ }^{[8]}$ Notably, 
the well-known processes of $\mathrm{S}-\mathrm{S}$ bond formation from thiol functionalities, which stabilize the tertiary structure of many proteins, take place by oxidative coupling, ${ }^{[9]}$ whereas in our case oxidation of $\mathbf{1}$ (either with $\mathrm{I}_{2}$ or $\mathrm{Ag}^{+}$) results in the scission of the $\mathrm{S}-\mathrm{S}$ bond.

The thione in $\mathbf{5}$ undergoes thiophilic addition by treatment with phosphanes, such as $\mathrm{PCy}_{3}$, to afford $\mathbf{6}$, a complex in which the diphosphane ligand contains a unique thioxophosphorane ylide functionality (Scheme 1). The same behavior is shown by complex 2 , which readily reacts with $\mathrm{PCy}_{3}$ by nucleophilic substitution of $\mathrm{I}^{-}$to give 6. Similar types of 1,3-dipolar molecules are assumed to be reaction intermediates in the well-known desulfurization and coupling reactions of 1,3dithiole-2-thiones by trialkylphosphites, which led to tetrathiafulvalene derivatives (constituents of organic conductors, Scheme 2$){ }^{[10]}$ as well as in the formation of phosphorus ylides

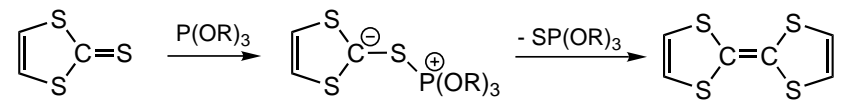

Scheme 2. Schematic representation of the desulfurization of 1,3-dithiole2-thiones by thiophilic addition of phosphites to give tetrathiafulvalene derivatives.

from thiones. ${ }^{[11]}$ However, this is the first time that such a derivative has been isolated and fully structurally characterized. The structure of $\mathbf{6} \cdot \mathrm{BF}_{4}$, which has been elucidated by X-ray crystallography (Figure 1$),{ }^{[12]}$ clearly shows the presence of the modified diphosphane ligand $\left[\left\{\left(\mathrm{PPh}_{2}\right)_{2} \mathrm{CSPCy}_{3}\right\} \eta^{2}\left(\mathrm{P}, \mathrm{P}^{\prime}\right)\right]$-coordinated to the $\mathrm{Mn}(\mathrm{CO})_{4}$ moiety. The P1-P2-C5-S skeleton departs appreciably from the expected planar conformation (the sulfur atom is at $0.644(2) \AA$ from the P1-P2-C5 plane), probably due to the

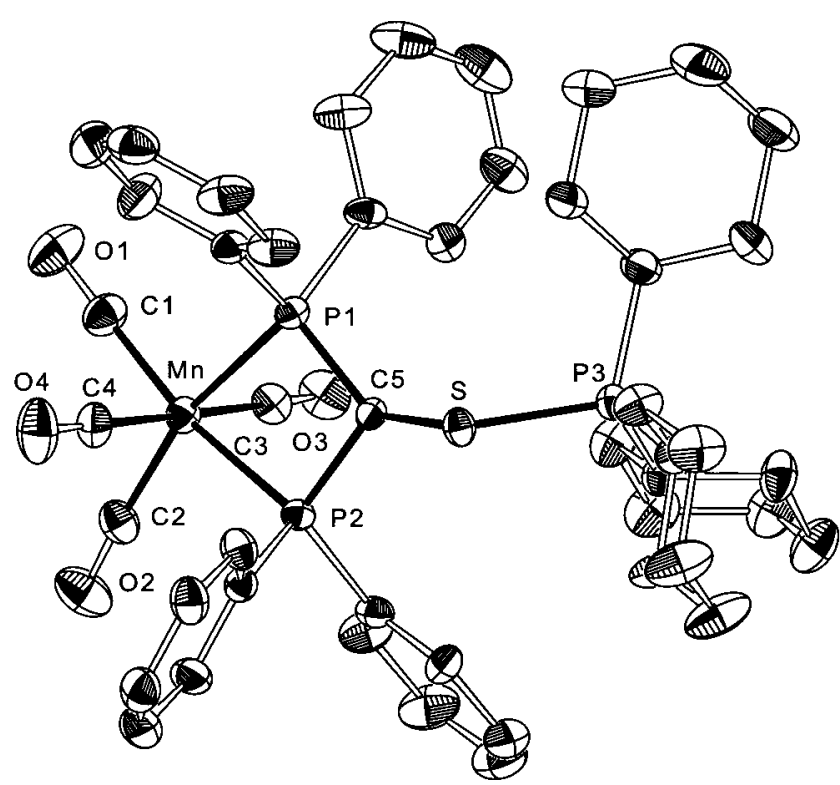

Figure 1. Structure of the cationic complex 6 in the crystal $(30 \%$ probability ellipsoids; hydrogen atoms are omitted for clarity). Selected bond lengths $\left[\AA \AA\right.$ ] and angles $\left[^{\circ}\right]$ : Mn-P1 2.342(2), Mn-P2 2.318(2), P1-C5 1.756(7), P2-C5 1.744(7), C5-S 1.760(7), S-P3 2.107(3); P1-Mn-P2 70.39(7), Mn-P1-C5 93.4(2), Mn-P2-C5 94.5(2), P1-C5-P2 100.3(3), P1-C5-S 131.2(4), P2-C5-S 121.9(4), C5-S-P3 116.0(2). steric hindrance of the cyclohexyl groups. The three bond lengths around the ylide carbon atom are slightly shorter than expected for single bonds (P1-C5 1.756(7), P2-C5 1.744(7), C5-S 1.760(7) ̊). The P1-P2-C5 and C5-S-P3 planes are almost mutually perpendicular (dihedral angle $79.0(3)^{\circ}$ ), which minimizes the steric repulsions between the cyclohexyl and phenyl rings. In the $\mathrm{S}-\mathrm{PCy}_{3}$ moiety the phosphorus atom has a distorted tetrahedral coordination geometry, and the $\mathrm{P}-\mathrm{S}$ distance (2.107 (3) $\AA$ ) is typical of a single bond.

The gentle warming of 6 in THF readily liberates $\mathrm{SPCy}_{3}$, thus completing the sulfur extrusion process from $\mathbf{5}$. However, the transient diphosphanylcarbene complex $\left[\mathrm{Mn}(\mathrm{CO})_{4^{-}}\right.$ $\left.\left\{\left(\mathrm{PPh}_{2}\right)_{2} \mathrm{C}:\right\}\right]^{+}$which should remain in the reaction mixture was not detected; instead a complex mixture of manganese(I) derivatives is found that still requires characterization.

In summary, the approach presented allows the reversible scission and formation of the $\mathrm{S}-\mathrm{S}$ bond in the dinuclear complex 1, which, in parallel, enables the generation of unusual functionalities at the central carbon atom of the diphosphane moiety. Preliminary results show that $\mathbf{2}$ and $\mathbf{5}$ undergo nucleophilic attack on the sulfur atom not only with tertiary phosphanes, but also with a wide variety of nucleophilic reagents such as $\mathrm{KCN}, \mathrm{MgRCl}$, and $\mathrm{NaSR}$. Thus these complexes show great promise for synthetic applications.

\section{Experimental Section}

2: $\mathrm{I}_{2}(0.022 \mathrm{~g}, 0.087 \mathrm{mmol})$ was added to a solution of $\mathbf{1}(0.1 \mathrm{~g}, 0.086 \mathrm{mmol})$ in $\mathrm{CH}_{2} \mathrm{Cl}_{2}$. After the mixture had been stirred for $5 \mathrm{~min}$ at room temperature, the solvent was evaporated to dryness, and the brown residue was recrystallized from $\mathrm{CH}_{2} \mathrm{Cl}_{2} /$ hexane to afford a red solid; yield $91 \%$ $(0.11 \mathrm{~g})$. Elemental analysis $(\%)$ calcd for $\mathrm{C}_{29} \mathrm{H}_{20} \mathrm{IMnO}_{4} \mathrm{P}_{2} \mathrm{~S}$ : C $49.18, \mathrm{H}$ 2.85; found: C 48.87, H 2.82; IR $\left(\mathrm{CH}_{2} \mathrm{Cl}_{2}\right): \tilde{v}=2081$ (s), 2011 (sh), 2001 (vs), $1982(\mathrm{~m}) \mathrm{cm}^{-1}(\mathrm{CO}) ;{ }^{31} \mathrm{P}\left\{{ }^{1} \mathrm{H}\right\}$ NMR $\left(121.5 \mathrm{MHz}, \mathrm{CD}_{2} \mathrm{Cl}_{2}\right): \delta=36.5$ (br); FAB-MS (positive-ion): $m / z: 708\left[M^{+}\right], 652\left[M^{+}-2 \mathrm{CO}\right]$

4: $\mathrm{IR}\left(\mathrm{CH}_{2} \mathrm{Cl}_{2}\right): \tilde{v}=2094$ (s), 2036 (m), 2011 (vs) $\mathrm{cm}^{-1}$ (CO); Raman (KBr): $\tilde{v}=451(\mathrm{~s}) \mathrm{cm}^{-1}(\mathrm{~S}-\mathrm{S}) ;{ }^{31} \mathrm{P}\left\{{ }^{1} \mathrm{H}\right\}$ NMR $\left(121.5 \mathrm{MHz}, \mathrm{CD}_{2} \mathrm{Cl}_{2}\right): \delta=34.0$ (br); ${ }^{1} \mathrm{H}$ NMR $\left(300 \mathrm{MHz}, \mathrm{CD}_{2} \mathrm{Cl}_{2}\right): \delta=6.98\left(\mathrm{t},{ }^{2} J_{\mathrm{P}, \mathrm{H}}=7 \mathrm{~Hz}, 2 \mathrm{H} ; \mathrm{P}_{2} \mathrm{CH}\right)$.

$\mathbf{5} \cdot \mathrm{BF}_{4}: \mathrm{AgBF}_{4}(0.35 \mathrm{~g}, 0.18 \mathrm{mmol})$ was added to a solution of $\mathbf{1}(0.1 \mathrm{~g}$, $0.086 \mathrm{mmol}$ ) in $\mathrm{CH}_{2} \mathrm{Cl}_{2}$. The resulting suspension, protected from light, was stirred for $1 \mathrm{~h}$. Then the solution was filtered off and evaporated to dryness. The residue was recrystallized twice in $\mathrm{CH}_{2} \mathrm{Cl}_{2} /$ hexane at $-20^{\circ} \mathrm{C}$ to afford white crystals; yield $40 \%(0.054 \mathrm{~g})$. Elemental analysis $(\%)$ calcd for $\mathrm{C}_{29} \mathrm{H}_{20} \mathrm{BF}_{4} \mathrm{MnO}_{4} \mathrm{P}_{2} \mathrm{~S}$ : C 52.13, H 3.02; found: C 52.03, H 2.96; IR $\left(\mathrm{CH}_{2} \mathrm{Cl}_{2}\right)$ : $\tilde{v}=2093(\mathrm{~s}), 2033(\mathrm{~m}), 2011$ (vs) $\mathrm{cm}^{-1}(\mathrm{CO}) ;{ }^{31} \mathrm{P}\left\{{ }^{1} \mathrm{H}\right\} \mathrm{NMR}(121.5 \mathrm{MHz}$, $\mathrm{CD}_{2} \mathrm{Cl}_{2}$ ): $\delta=44.0$ (br); FAB-MS (positive-ion): $m / z: 581\left[M^{+}-\mathrm{BF}_{4}\right]$.

$\mathbf{6} \cdot \mathrm{BF}_{4}: \mathrm{PCy}_{3}(0.025 \mathrm{~g}, 0.09 \mathrm{mmol})$ was added to a solution of $\mathbf{5} \cdot \mathrm{BF}_{4}(0.06 \mathrm{~g}$, $0.09 \mathrm{mmol}$ ) in $\mathrm{CH}_{2} \mathrm{Cl}_{2}$. After the mixture had been stirred for $20 \mathrm{~min}$ at room temperature, the solvent was evaporated to dryness. The residue was washed with $\mathrm{Et}_{2} \mathrm{O}(20 \mathrm{~mL})$ and recrystallized from $\mathrm{CH}_{2} \mathrm{Cl}_{2} / \mathrm{Et}_{2} \mathrm{O}$ to obtain white crystals; yield $70 \%(0.06 \mathrm{~g})$. Elemental analysis $(\%)$ calcd for $\mathrm{C}_{47} \mathrm{H}_{53} \mathrm{BF}_{4} \mathrm{MnO}_{4} \mathrm{P}_{3} \mathrm{~S}$ : C 59.51, H 5.63; found: C 59.10, H 5.88; IR $\left(\mathrm{CH}_{2} \mathrm{Cl}_{2}\right)$ : $\tilde{v}=2079$ (s), 2014 (s), 1988 (vs) $\mathrm{cm}^{-1}$ (CO); ${ }^{31} \mathrm{P}\left\{{ }^{1} \mathrm{H}\right\}$ NMR $(121.5 \mathrm{MHz}$, $\left.\mathrm{CD}_{2} \mathrm{Cl}_{2}\right): \delta=32.4$ (br), $53.5\left(\mathrm{t},{ }^{3} J_{\mathrm{P}, \mathrm{P}}=7 \mathrm{~Hz}\right)$.

Received: July 31, 2000 [Z15557]

[1] J. J. R. Fraústo da Silva, R. J. P. Williams, The Biological Chemistry of the Elements, Clarendon, Oxford, 1991, pp. 164-170.

[2] P. Versloot, M. van Duin, J. G. Haasnoot, J. Reedijk, A. L. Spek, J. Chem. Soc. Chem. Commun. 1993, $183-184$; K. Ganesh, K. Kishore, Macromolecules 1996, 29, 26-29.

[3] D. L. Rabenstein, P. L. Yeo, J. Org. Chem. 1994, 59, 4223-4229. 
[4] J. Ruiz, V. Riera, M. Vivanco, M. Lanfranchi, A. Tiripicchio, Organometallics 1996, 15, 1082-1083.

[5] The crystal structure of $\mathbf{1}$ has been determined as part of a detailed study of the sulfur extrusion and protonation processes of these polysulfide derivatives: J. Ruiz, M. Ceroni, O. Quinzani, V. Riera, M. Vivanco, M. Lanfranchi, A. Tiripicchio, unpublished results.

[6] K. Goto, M. Holler, R. Okazaki, Chem. Commun. 1998, 1915-1916.

[7] H. Schmidbaur, C. E. Zybill, D. Neugebauer, Angew. Chem. 1982, 94, 321; Angew. Chem. Int. Ed. Engl. 1982, 21, 310-311; Angew. Chem. Suppl. 1982, 590-605.

[8] H. Schmidbaur, C. E. Zybill, D. Neugebauer, Angew. Chem. 1983, 95, 161; Angew. Chem. Int. Ed. Engl. 1983, 22, 156-161; Angew. Chem. Suppl. 1983, 169-183.

[9] R. W. Hay, Bio-Inorganic Chemistry, Ellis Horwood, Chichester, 1987, p. 31.

[10] R. P. Parg, J. D. Kilburn, T. G. Ryan, Synthesis 1994, 195-198, and references therein.

[11] A. Bulpin, S. Masson, A. Sene, Tetrahedron Lett. 1990, 31, 1151-1154, and references therein.

[12] Crystal data for 6. $\mathrm{BF}_{4}\left(\mathrm{C}_{47} \mathrm{H}_{53} \mathrm{BF}_{4} \mathrm{MnO}_{4} \mathrm{P}_{3} \mathrm{~S}\right): M_{\mathrm{r}}=948.61$, triclinic, space group $P 1, a=11.771(2), b=13.909(2), c=16.416(4) \AA, \alpha=$ 67.69(1), $\beta=82.86(2), \gamma=81.43(1)^{\circ}, V=2452.8(8) \AA^{3}, Z=2, \rho_{\text {calcd }}=$ $1.285 \mathrm{~g} \mathrm{~cm}^{-3}, \quad F(000)=988, \quad \mathrm{Mo}_{\mathrm{K} \alpha}$ radiation $(\lambda=0.71073 \AA)$, $\mu\left(\mathrm{Mo}_{\mathrm{K} a}\right)=0.191 \mathrm{~mm}^{-1}$; crystal dimensions $0.10 \times 0.28 \times 0.40$. Diffraction data were collected on an Enraf-Nonius diffractometer at $293 \mathrm{~K}$. The structure was solved by direct methods and refined using fullmatrix least-squares on $F^{2}$ with all non-hydrogen atoms anisotropically defined. The hydrogen atoms were placed in calculated positions, isotropically refined with common thermal parameters and allowed to ride on their parent carbon atoms. For 4866 observed reflections with $I>2 \sigma(I)$ and 551 parameters, the conventional $R$ is 0.081 and $w R 2=$ 0.252 . Crystallographic data (excluding structure factors) for the structure reported in this paper have been deposited with the Cambridge Crystallographic Data Centre as supplementary publication no. CCDC-145733. Copies of the data can be obtained free of charge on application to CCDC, 12 Union Road, Cambridge CB21EZ, UK (fax: (+44)1223-336-033; e-mail: deposit@ccdc.cam. ac.uk).

\section{Efficient Catalytic Alkane Nitration with $\mathrm{NO}_{2}$ under Air Assisted by $\mathrm{N}$-Hydroxyphthalimide**}

\section{Satoshi Sakaguchi, Yoshiki Nishiwaki,} Takaaki Kitamura, and Yasutaka Ishii*

In contrast to the nitration of aromatic hydrocarbons, which is easily performed using nitric acid in the presence of sulfuric acid, the selective nitration of aliphatic hydrocarbons is very difficult because of the exceedingly low reactivity of the latter. Currently, nitrations of aliphatic hydrocarbons are carried out at fairly high temperatures $\left(250-400^{\circ} \mathrm{C}\right)$ using nitrogen dioxide or nitric acid, and they proceed by free radical chain

[*] Prof. Y. Ishii, S. Sakaguchi, Y. Nishiwaki, T. Kitamura Department of Applied Chemistry

Faculty of Engineering and High Technology Research Center

Kansai University, Suita, Osaka 564-8680 (Japan)

Fax: (+81)6-6339-4026

E-mail: ishii@ipcku.kansai-u.ac.jp

[**] This work was supported by the Research for the Future program, JSPS.

Supporting information for this article is available on the WWW under http://www.angewandte.com or from the author. reactions involving $\mathrm{C}-\mathrm{H}$ bond homolysis. ${ }^{[1,2]}$ Under such high temperatures, higher alkanes undergo not only homolysis of $\mathrm{C}-\mathrm{H}$ bonds but also cleavage of the $\mathrm{C}-\mathrm{C}$ skeleton. Therefore, large-scale nitration of alkanes has been limited to lower alkanes such as methane and ethane. ${ }^{[2]}$ For instance, the nitration of propane produces all of the possible nitroparafins, namely, nitromethane, nitroethane, 1-nitropropane, and 2-nitropropane. ${ }^{[1,3]}$ The development of selective nitration of cyclohexane is very attractive, since nitrocyclohexane is easily converted into cyclohexanone oxime, the raw material of $\varepsilon$ caprolactam, which in turn leads to nylon-6. ${ }^{[4-6]}$

Recently we developed a catalytic method for the generation of alkyl radicals from saturated hydrocarbons using $\mathrm{N}$ hydroxyphthalimide (NHPI), which serves as the radical catalyst. ${ }^{[7]}$ The phthalimide $N$-oxyl (PINO) radical generated in situ from NHPI and $\mathrm{O}_{2}$, which lies in a triplet state, abstracts the hydrogen atom from the saturated hydrocarbons, forming the corresponding alkyl radicals. These radicals are readily trapped by $\mathrm{O}_{2}$ under aerobic conditions to give oxygen-containing compounds such as alcohols, ketones, and carboxylic acids. These results led us to become interested in the nitration of alkanes with $\mathrm{NO}_{2}$ by the use of NHPI as a catalyst.

In the first trial, NHPI was added at room temperature to a stirred benzene solution containing dissolved $\mathrm{NO}_{2}$. The ESR measurement of the solution indicated a triplet signal, which is assigned to the PINO radical. ${ }^{[8]}$ This is believed to be due to the fact that $\mathrm{NO}_{2}$ is a stronger oxidant than $\mathrm{O}_{2}$. Thus, the nitration of cyclohexane (1) was examined using $\mathrm{NO}_{2}$ in the presence of a catalytic amount of NHPI under several reaction conditions ([Eq. (1)], Table 1).



The nitration of $\mathbf{1}$ with $\mathrm{NO}_{2}$ by NHPI proceeded smoothly at $70{ }^{\circ} \mathrm{C}$ to give nitrocyclohexane $\left(\mathbf{2}, 70 \%\right.$ based on $\mathrm{NO}_{2}$ used; Table 1 , run 1$)$ and cyclohexyl nitrite $(\mathbf{3}, 7 \%)$ along with a small amount of an oxygenated product, cyclohexanol (5\%).

Table 1. NHPI-catalyzed nitration of $\mathbf{1}$ with $\mathrm{NO}_{2}$ under selected conditions. ${ }^{[a]}$

\begin{tabular}{lllc}
\hline Run & NHPI $[\mathrm{mmol}]$ & $T\left[{ }^{\circ} \mathrm{C}\right]$ & ${\text { Yield of } 2[\%]^{[\mathrm{b}]}}^{-}$ \\
\hline 1 & 0.6 & 70 & 70 \\
$2^{[\mathrm{c}]}$ & 0.6 & 70 & 43 \\
3 & - & 70 & $<2$ \\
4 & 0.6 & 60 & 58 \\
5 & 0.6 & 50 & 39 \\
6 & 0.3 & 70 & 56 \\
$7^{[\mathrm{d}]}$ & 0.6 & 70 & 63 \\
$8^{[\mathrm{e}]}$ & 9 & 70 & 53 \\
\hline
\end{tabular}

[a] Reactions were run as described in the Experimental Section. [b] Yields are average values obtained from several runs and are based on $\mathrm{NO}_{2}$ used. [c] Under argon. [d] Recovered catalyst from run 1 was used. [e] The reaction was carried out using $\mathbf{1}(50 \mathrm{~mL})$ and $\mathrm{NO}_{2}(33 \mathrm{mmol})$. The yield of 2 is based on isolated product. 